\title{
Wind erosion design considerations for closure of tailings storage facilities in South Africa: a case study
}

\author{
SJ van Wyk Agreenco Environmental Projects (Pty) Ltd, South Africa \\ J Hatting Agreenco Environmental Projects (Pty) Ltd, South Africa \\ ASH Haagner Agreenco Environmental Projects (Pty) Ltd, South Africa
}

\begin{abstract}
Environmental pressure is ever mounting on mining companies to prove that mine residue facilities will be stable landforms after closure. Designing tailings storage facilities (TSFs) for reduced dust emissions is also not readily considered as part of the tailings engineering process, and most TSFs are still uncovered in South Africa. This paper advocates proactively engineered, wind resistant tailings landscapes by incorporating principles of aerodynamic design into final closure design content. This is imperative in the wake of much dryer, windier, and warmer climate predicted for sub-Saharan Africa. This paper considers tailings specific wind erosion scenarios modelled from field data for a large TSF in South Africa. The revised wind erosion equation is applied to determine comparative wind erosion scenarios for geometric variation that informs the landscape engineering process. The methodology considers local climate, surrounding regional relief (wind direction and energy scenarios), TSF construction methodology (particulate grading and segregation), geometrical design (wind speed amplification), and material physical and chemical characteristics (particle size, moisture regimes, and dispersion properties). The modelled output demonstrates that wind erosion exponentially increases on unprotected slopes with an increase in slope angle comparing 14,18 , and $26^{\circ}$ slope angles, implying that uncovered tailings landscapes should be designed much flatter to withstand wind erosivity over time. Mitigation scenarios are incorporated into the model to evaluate effectiveness of surface protection considering the scale of high dust risk areas and the degree of effectiveness that can be expected. The outcomes of this study suggest that unless the substantial effects of wind are not considered during the geometrical design and final closure landscape planning stages, uncovered tailings landscapes will remain serious sources of dust pollution. A case is made that wind erosion should be incorporated as a matter of principle closure design of TSFs.
\end{abstract}

Keywords: wind erosion, tailings dust, closure design, revised wind erosion equation

\section{Introduction}

Designing tailings landscapes for closure has become integrally part of the tailings engineering thought process and design principles as tailings structures need to stand the test of time against natural erosive forces. Mine residue facilities and tailings facilities are obstructions to airflow in the landscape. Considering the principles of dust generation from natural landscapes, we know that anthropogenic stockpiles with similar characteristics will behave somewhat like dunes (Shao 2008; Singh 1994; Vermeulen 2001, Amponsah-Dacosta \& Blight 2002; Blight 2008; Rademeyer 2007; Liebenberg-Enslin 2014; Van Wyk 2015). There is a thorough understanding of dust mechanics, tailings construction methodology, and more recently, particulate dispersion modelling, however, these fields of expertise have not yet been integrated to any meaningful extent to improve design. Wind erosion and associated dust emissions from tailings facilities can therefore be regarded as a symptom of design inefficiencies and can be proactively considered if holistic design is appreciated and applied.

Justifiable public outcries about the contribution of mines to poor air quality through 'aerial spills' have triggered the legislative and reporting era which have introduced dust monitoring, emission standards, and proactive dust interventions as standard practices around tailings environmental management. 
The application of particulate emission information into two emerging fields of environmental risk management-being climate change risk assessment and tailings closure design-have not been fully appreciated to date. Environmental pressure is ever mounting on mining companies to prove that mine residue facilities will be stable landforms after closure. Consideration of the effect and contribution of wind erosion on minescapes are, however, not part of routine design practices or final closure risk assessment in South Africa; long-term dust control has, in many cases, been an afterthought during both the operational and closure aspirations of tailings facilities. The result is that numerous legacy tailings storage facilities (TSFs), which are still uncovered and unrehabilitated, have become sources of particulate emitters. The combination of erosive forces of wind and water will, however, challenge the integrity of the facilities after closure.

By incorporating wind erosion information into closure design and applying principles of landscape aerodynamics, it is our theory that tailings structures can be designed to shed energy by designing more streamlined facilities that will aid airflow and reduce shear in the landscape. This will lead to reduced erosive forces that will constantly attack tailings slopes and covers and emission of particulate matter into the environment.

Designers of tailings landforms must respond to the increasingly complex questions of perceptive pressure around environmental health protection (particulate matter, precipitates, and radionuclides), improved visibility around mine roads, reducing nuisance dust, containment of environmental contamination, and protection of ecosystem services. Furthermore, the increasing importance of the incorporation of climate change drivers revolving around dust emissions on mines will become a design imperative for the future.

This paper contributes to the context and effect of geometrical design criteria from an air quality perspective by means of a wind erosion modelling case study. Geometrical scenarios are compared from field data to demonstrate comparative erosive losses from the design options. This methodology sheds light on how principles of aerodynamics can be incorporated in the design and operation of TSFs and associated surface shear scenarios be considered during the planning and design phase. This approach can lead to more wind resistant closure landforms.

\section{Problem statement and methodology}

\subsection{Case study background}

A large-scale TSF in the north-eastern Limpopo province of South Africa is nearing its end of life. The facility is hydraulically constructed with the mine's porphyritic phosphorite tail by means of large cyclones. This methodology enables the disposal of more than $2 \mathrm{Mt}$ per month at rate of rise in excess of 6-9 $\mathrm{m}$ per year and long stable slopes. The slopes lengths are in excess of $100 \mathrm{~m}$ and constructed at angle of repose $\left(26^{\circ}\right)$. The cyclone deposition strategy has greatly improved water use efficiency (which has rapidly become a scarce commodity) and cycle time on the TSF is between 30 and 36 months rendering vast surface areas dry throughout the year. The facility is known for frequently high dust fallout events on the back of low rainfall and constant south-easterly breezes. The sheer size of the facility (in excess of 1,400 ha) make it virtually impossible to manage without substantial volume of stored water. The tailings material is coarse, dry, highly alkaline, and devoid of nutrients that render it inhospitable for vegetation establishment without topsoil cover.

Air quality has become a serious concern for the public living near the mine, and conservationists have added their voice of concern about the fate of the landscape as the mine borders an extremely sensitive environment. The mine is running out of cover material and the beach area will not be covered with the routine soil and rock matrix. The mine has also run dry over time and limited water is available for revegetation of the chemically complex tailings material.

Our task was to carry out a dust risk assessment and to generate information that would inform landscape characteristics that need to be optimised to reduce dust fallout in the absence of topsoil cover, revegetation, and irrigation water. This information would provide geometrical scenarios for reduced wind erosion from and air quality and closure perspective. We outlined the following study objectives to advise the mine: 
- Determine what the effect of variable slope angle $\left(14,18\right.$, and $\left.26^{\circ}\right)$ on wind erosivity would be for a facility with a slope length of $100 \mathrm{~m}$ would be for the phosphorite TSF considering a vertical height of $30 \mathrm{~m}$.

- To evaluate the unmitigated and mitigated effects on wind erosion loss from a TSF beach field.

- To recommend design alternatives that would inform tailings closure scenarios from a wind erosion and future air quality perspective.

\subsection{Study approach}

The following approach was implemented to carry out the dust risk assessment for the tailings facility and to address the problem questions above. The methodology applied is well documented by Pasak (1967), Fryrear et al. (1998), Visser (2004), Van Wyk (2010, 2015), and Haagner et al. (2014):

- To collate site-specific, field-based information required to feed into the selected wind erosion model discussed in subsection 2.3.

- To conduct a wind erosion modelling exercise to generate the expected rates of soil loss under a supplied set of geometrical scenarios and cover scenarios. The revised wind erosion equation (RWEQ) was selected as the best model to deliver the required design output.

- Other physically based simulation models such as the Wind Erosion Prediction System (WEPS) (Hagen 1991) and DREAM (Dust Regional Atmospheric Modelling) models was evaluated but due to these models' temporal and spatial scale applications and lack of correlation on field scale input drivers and dust fallout, we opted for the use of RWEQ.

- To delineate all priority dust source areas into dust management units that share similar dust generation risk values given the average and acute weather by means of a series of calculated weather factors.

\subsection{Application of the revised wind erosion equation}

The RWEQ quantifies soil eroded and transported by wind between the soil surface and a height of $2 \mathrm{~m}$ considering the environmental input drivers and the modelled output is well correlated with actual fallout data measured across a range of field applications (Fryrear et al. 1998). The RWEQ model-an improvement on the wind erosion equation (WEQ) model-assumes that natural wind is the driving force of the erosion process. The WEQ was the first empirical model to assess soil erosion by wind. It is most applicable for problems of erosion from the field but also provides information on erosion rate effects within the field. This model has been proven to improve estimates of erosion, allows more flexibility in inputs, and enhances output (Fryrear et al. 1998).

RWEQ utilises monthly weather data, soil and field data, and management inputs. The model considers and incorporates site-specific and temporally segmented wind energy, surface stability and flux characteristics and express wind erosion output in $\mathrm{kg} \mathrm{m}^{-2}$ year ${ }^{-1}$. Wind energy output is determined through the weather factor (WF). The WF incorporate a wind factor (Wf), air density, gravity induced acceleration and soil wetness to explain particulate emission potential as a function of energy regimes. The $\mathrm{Wf}$ in the equation is calculated from the Weibull coefficients $k$ and $c$, percent calm, and the cumulative probability distribution. The RWEQ divides the probability values that range from 0 and 0.999 into 500 uniformly distributed probability values. These probability values are used with the Weibull coefficients and percent calm to compute 500 wind speeds for each period. These computed 10-metre wind speeds are converted to the equivalent 2-metre wind speeds to produce the Wf. The total $\mathrm{Wf}$ for each period is determined by dividing the total wind value for each period by 500 and multiplying by the number of days in the period.

Time periods from the management input file are used to partition the WF for each 1-15-day time period. The dominant wind direction for each period is determined and the $\mathrm{Wf}$ is computed for four directions based on preponderance and positive parallel ratio values from the weather files. Secondly, adjustments are then made in wind energy for hill and surface effects and soil wetness. The management inputs include cropping systems, 
tillage and time period dates, surface descriptions, and, where applicable, irrigation information. Thirdly, operation dates are used to determine time periods for computations of residue decay, soil roughness decline, and soil erosion. Soil roughness is decayed for each time period based on rainfall characteristics and soil physical properties, i.e. clay content (Fryrear et al. 1998). Fourthly, all the information is considered for single wind event applications (not annual averages compared to other models), whereby the input is applied to a critical field length(s) calculated based on the erosive plain characteristics, energy regime on the surface, mitigating factors, if any, and the resultant flux carrying potential. As most of the wind erosion influencing variables are changing throughout a year the conditions during the critical wind erosion period are used in RWEQ to derive an estimate of annual wind erosion. The critical wind erosion period is described as the period of the year when the greatest amount of wind erosion can be expected to occur from a field under an identified management system. It is the period when vegetative cover, soil surface conditions, and expected erosive winds result in the greatest potential for wind erosion.

Accurate dust emissions can be generated for the varying input scenarios considering the surface area of the tailings facility. Equation 1 summarises how the erosion rates are calculated through RWEQ. Note that each of these variables is composed of sub-variables and complex sub-formulas which are outlined as sub-bullets below. Each of the variables and for the purposes of the length of the paper is not outlined in detail.

$$
E=f(C, I, K, C, L, V)
$$

where:

$\mathrm{E} \quad=$ Potential annual soil loss (in $\left.\mathrm{t} \mathrm{ha}^{-1} \mathrm{yr}^{-1}\right)$.

$\mathrm{f} \quad=$ Indication that the equation includes functional relationships that are not straight-line mathematical calculations.

$\mathrm{C}=$ Index of climatic erosivity, specifically wind speed and surface soil moisture. The factor for any given location is a function of climatic energy data (weather, wind, geo-amplification and wetness factors).

$1=$ Soil erodibility, expressed as potential annual soil loss in ( $\left.\mathrm{t} \mathrm{ha-1} \mathrm{yr}^{-1}\right)$ from a wide, unsheltered isolated field with bare, smooth, level, loose, and non-crusted surface considering reference climatic factors.

$\mathrm{K}=$ Surface roughness factor considering the surface sheer absorbing and deflecting wind energy and trap moving soil particles.

$\mathrm{V} \quad=$ The equivalent vegetation cover expressed by relating the kind, amount, and orientation of vegetative material to its equivalent in $\mathrm{kg} \mathrm{ha}^{-1}$ of small grain residue in reference condition (SGe).

$\mathrm{L} \quad=\quad$ The unsheltered field length, expressed as weighted travel distance $(\mathrm{m})$ along the prevailing wind direction (filed length and mass transport factors).

RWEQ consider all this input data to compute the mass transport output of wind eroded material. Mass transport (Q) varies with soil texture, soil surface, field length, and climatic conditions (Fryrear \& Saleh 1993; Stout \& Zobeck 1996).

The capacity of the wind to erode and transport soil also limits the increase in transport mass when field length is greater than the critical field length(s). Thus, transport mass for any field the coefficients $\left(Q_{\max }\right.$ and $s$ ) can be estimated from known field conditions but must account for the true field length. The measured $Q_{\max }$ for individual events in instrumented fields was determined from transport mass (total airborne mass from soil surface to height of $2 \mathrm{~m}$ ) and field length data values. The capacity of the wind to erode and transport soil limits the increase in transport mass when field length is greater than the critical field length The mass transport value is therefore divided by the critical field length to determine how much material will be liberated from the tailings surface. This can be described by Equation 2 which is the heart of the RWEQ. 


$$
\mathrm{Q}(\mathrm{x}+\Delta \mathrm{x})=\mathrm{Q}(\mathrm{x})+\left(\left(\mathrm{Q}_{\max }(\mathrm{x})-\mathrm{Q}(\mathrm{x})\right) / \mathrm{s}(\mathrm{x})\right) \cdot(2 \mathrm{x} / \mathrm{s}(\mathrm{x}) \cdot \Delta \mathrm{x}
$$

where

$\begin{array}{lll}Q(x) & = & \text { Mass transport at downwind distance } x, \mathrm{~kg} / \mathrm{m} \text { width. } \\ Q_{\max }(x)= & \text { Maximum transport, } \mathrm{kg} / \mathrm{m} \text { width. } \\ S_{r}(x)= & \text { Surface retention coefficient. } \\ x & = & \text { Distance from the upwind edge of the field, } \mathrm{m} . \\ b(x) & = & \text { Field length scale, } \mathrm{m} .\end{array}$

Critical field lengths for individual events were computed using least square analysis of the transport mass field length data and regressing wind, soil, and crop parameters for the calculated (adjusted) field lengths.

\section{RWEQ results and analysis}

This section of the paper predominantly depicts the RWEQ model output derived from the equations in order to answer the problem questions.

\subsection{Climate data and wind erosivity (C-Factor)}

The study area is in the north-eastern part of Limpopo province of South Africa which has strong cyclical tendencies and the region experiences summer rainfall (peaks from December to February) with very dry winters. The mean annual precipitation is $500 \mathrm{~mm}$ and the region is generally free of frost. The mean annual temperature is $21.2^{\circ} \mathrm{C}$, with average maximum temperatures in December around $30^{\circ} \mathrm{C}$ and in July around $25^{\circ} \mathrm{C}$. The combination of high average temperatures and low annual rainfall results in very high levels of mean annual potential evaporation, in the order of 2,035 $\mathrm{mm}$. This means that the potential evaporation outstrips the annual rainfall by a factor of $80 \%$. Wind patterns, in terms of direction, frequency, average speed, and maximum speeds and duration have an even greater influence on the dust risk profile. The wind roses for four months, representing seasonality, are depicted in Figure 1a for January and April, and Figure $1 \mathrm{~b}$ for July and October.
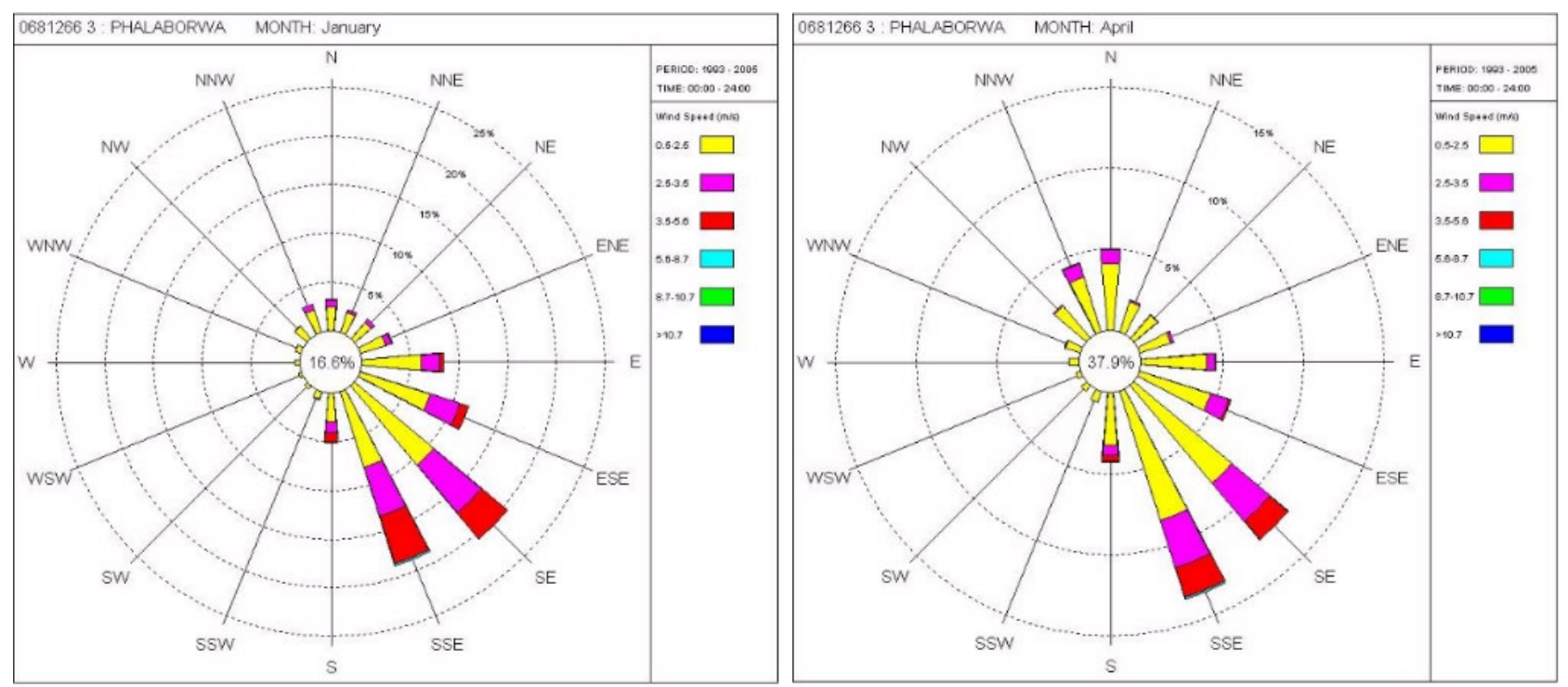

Figure 1a Wind roses for the months of January, and April indicating relative direction, speed, and frequency. The weather data was sourced from the Ba-Phalaborwa weather station (South African Weather Service 2008) 


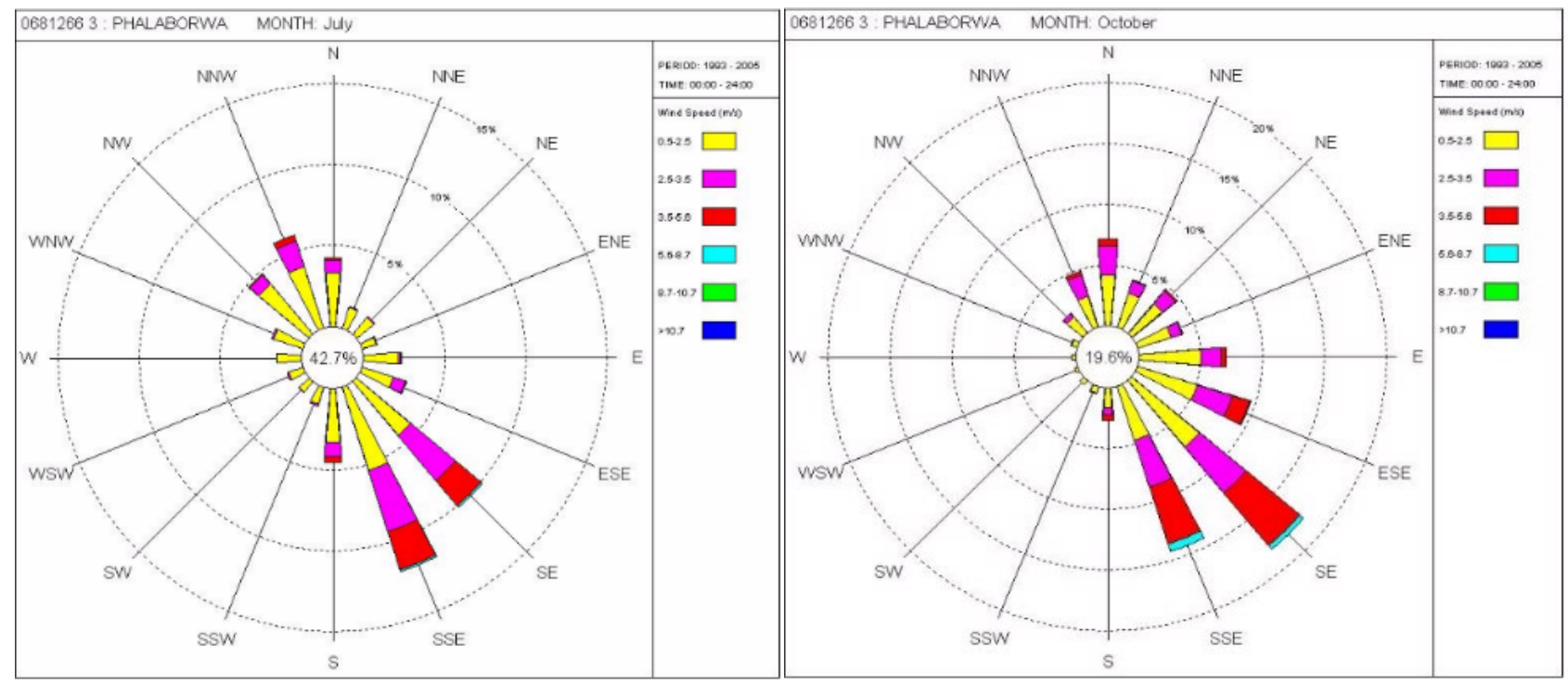

Figure $1 \mathrm{~b}$ Wind roses for the months of July, and October indicating relative direction, speed, and frequency. The weather data was sourced from the Ba-Phalaborwa weather station (South African Weather Service 2008)

Only the data from key comparative months are presented in Figures $1 a$ and $1 b$, to demonstrate the increase in wind speed and wind intensity towards the end of the year. The wind direction is predominantly from the southeast which will influence the outcome of the dust risk assessment and inform the high dust generation risk areas.

The measured hourly wind speed was used to calculate the Weibull constants at the height that the wind speed was measured $(10 \mathrm{~m})$. These constants were converted to a wind speed at $2 \mathrm{~m}$ height and wind values, $\mathrm{Wf}$, and WF were calculated and are presented in the final table. From the data presented in Table 1, March and October 2008 presented the least calm conditions.

Table 1 The Weibull constants for the 2008 wind data depicting wind energy input values at a height above land at $10 \mathrm{~m}$ and $2 \mathrm{~m}$ at 15 -day intervals starting January 2008 (continued next page)

\begin{tabular}{lllllll}
\hline Interval (15 days) & Calm\% & $\mathbf{k 1 0}$ & $\mathbf{c 1 0}$ & $\mathbf{n}$ & $\mathbf{k 2}$ & $\mathbf{c 2}$ \\
\hline $\mathbf{1}$ to 15 & 4.17 & 2.34 & 3.13 & 0.27 & 2.05 & 2.03 \\
$\mathbf{1 6}$ to 30 & 3.06 & 3.16 & 3.31 & 0.26 & 2.77 & 2.16 \\
$\mathbf{3 1}$ to $\mathbf{4 5}$ & $\mathbf{2 . 2 2}$ & $\mathbf{3 . 4 5}$ & $\mathbf{3 . 6 7}$ & $\mathbf{0 . 2 6}$ & $\mathbf{3 . 0 2}$ & $\mathbf{2 . 4 3}$ \\
$\mathbf{4 6}$ to 60 & $\mathbf{4 . 1 7}$ & $\mathbf{3 . 1 8}$ & $\mathbf{3 . 2 7}$ & $\mathbf{0 . 2 7}$ & $\mathbf{2 . 7 8}$ & $\mathbf{2 . 1 3}$ \\
$\mathbf{6 1}$ to $\mathbf{7 5}$ & $\mathbf{3 . 8 9}$ & $\mathbf{3 . 5 0}$ & $\mathbf{3 . 2 7}$ & $\mathbf{0 . 2 7}$ & $\mathbf{3 . 0 7}$ & $\mathbf{2 . 1 3}$ \\
$\mathbf{7 6}$ to 90 & 10.83 & 1.90 & 3.36 & 0.26 & 1.67 & 2.20 \\
$\mathbf{9 1}$ to 105 & 12.22 & 2.91 & 2.67 & 0.28 & 2.54 & 1.69 \\
$\mathbf{1 0 6}$ to 120 & 6.11 & 3.34 & 2.66 & 0.28 & 2.93 & 1.69 \\
$\mathbf{1 2 1}$ to 135 & 9.44 & 2.05 & 2.91 & 0.28 & 1.80 & 1.86 \\
$\mathbf{1 3 6}$ to 150 & 13.06 & 3.20 & 2.43 & 0.29 & 2.80 & 1.52 \\
$\mathbf{1 5 1}$ to 165 & 9.44 & 2.61 & 2.93 & 0.28 & 2.29 & 1.88 \\
$\mathbf{1 6 6}$ to 180 & 11.11 & 3.74 & 2.37 & 0.29 & 3.28 & 1.48 \\
$\mathbf{1 8 1}$ to 195 & 4.72 & 2.86 & 2.96 & 0.27 & 2.51 & 1.91
\end{tabular}




\begin{tabular}{lllllll}
196 to 210 & 9.17 & 2.63 & 2.88 & 0.28 & 2.31 & 1.84 \\
211 to 225 & 4.44 & 2.65 & 3.08 & 0.27 & 2.33 & 1.99 \\
226 to 240 & 9.44 & 2.02 & 3.27 & 0.27 & 1.77 & 2.13 \\
$\mathbf{2 4 1}$ to 255 & $\mathbf{5 . 0 0}$ & $\mathbf{2 . 1 5}$ & $\mathbf{3 . 9 0}$ & $\mathbf{0 . 2 5}$ & $\mathbf{1 . 8 9}$ & $\mathbf{2 . 6 1}$ \\
$\mathbf{2 5 6}$ to 270 & $\mathbf{3 . 6 1}$ & $\mathbf{2 . 5 2}$ & $\mathbf{4 . 0 8}$ & $\mathbf{0 . 2 5}$ & $\mathbf{2 . 2 1}$ & $\mathbf{2 . 7 4}$ \\
$\mathbf{2 7 1}$ to 285 & $\mathbf{5 . 5 6}$ & $\mathbf{2 . 4 1}$ & $\mathbf{4 . 3 9}$ & $\mathbf{0 . 2 4}$ & $\mathbf{2 . 1 1}$ & $\mathbf{2 . 9 8}$ \\
$\mathbf{2 8 6}$ to 300 & 3.61 & 2.02 & 4.04 & 0.25 & 1.77 & 2.72 \\
301 to 315 & 10.00 & 2.07 & 3.87 & 0.25 & 1.81 & 2.58 \\
316 to 330 & 26.67 & 2.22 & 2.77 & 0.28 & 1.95 & 1.77 \\
331 to 345 & 25.83 & 1.80 & 2.84 & 0.28 & 1.58 & 1.81 \\
346 to 360 & 6.39 & 2.24 & 3.81 & 0.25 & 1.96 & 2.53 \\
\hline
\end{tabular}

\subsection{Tailings erodibility}

The tailings beach was sampled from the pool or the wet zone outwards towards the crest. The samples were put through seven-fraction analyses to evaluate whether the beach was well graded as expected from a conventional hydraulically stacked TSF profile. The particle size analysis was used to calculate the erodible fraction, the potential dust generation fraction, and the water contents of the tailings material. Figure 2 presents the sampling points on the TSF.

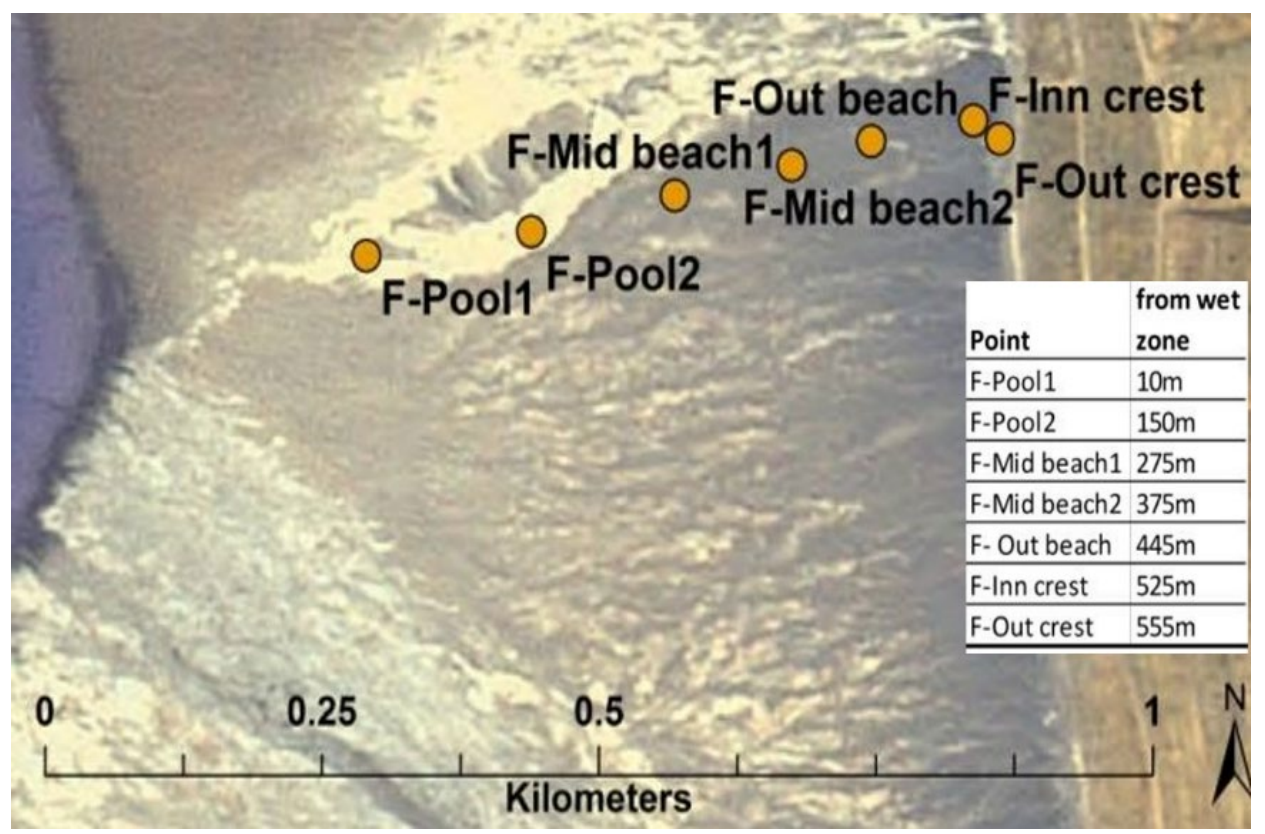

Figure 2 Sampling points from the pool outward to the crest along the beach of the TSF

Table 2 presents the soil physical results and its associated erodibility as well as soil wetness characteristics at air dry (AD) and drained upper limit (DUL) conditions. The results indicate that there is limited grading of the particle size distribution, but crest samples were slightly coarser and as expected the material were finer around the pool area. Since the material is poorly graded it offers the perfect scenario in this study that factors other than grading may have a greater influence on the main erodibility drivers. 
Table 2 The particle fractions of significance in wind erosion, wind erodible fractions, and resulting soil wetness expressed in terms of air dry (AD), drained upper limit (DUL), and saturated (Wsat) conditions

\begin{tabular}{|c|c|c|c|c|c|c|c|c|c|c|}
\hline \multirow[b]{2}{*}{ Position } & \multicolumn{7}{|c|}{ Erodible fraction and dust generation fraction } & \multicolumn{3}{|c|}{ Soil wetness } \\
\hline & Sand\% & Silt\% & Clay\% & $\begin{array}{l}\text { Erodi- } \\
\text { bility }\end{array}$ & $\begin{array}{l}\%<840 \\
\text { um }\end{array}$ & $\begin{array}{l}\%<26 \\
\text { um }\end{array}$ & $\begin{array}{l}\%<P M \\
10\end{array}$ & AD & DUL & WSat \\
\hline FP1 10m f pool & 97.6 & 0.2 & 2.2 & 0.74 & 97 & 2.3 & 2.2 & 0.01 & 0.112 & 0.420 \\
\hline FP2 100m f Pool & 97.6 & 0.2 & 2.1 & 0.75 & 97 & 2.2 & 2.1 & 0.01 & 0.111 & 0.420 \\
\hline FP3 200m f pool & 97.6 & 0.2 & 2.1 & 0.75 & 95 & 2.2 & 2 & 0.01 & 0.111 & 0.420 \\
\hline FP4 280m f pool & 97.6 & 0.2 & 2.1 & 0.75 & 95 & 2.2 & 1.9 & 0.01 & 0.111 & 0.420 \\
\hline FP5 380m f pool & | 97.6 & 0.2 & 2.1 & 0.75 & 90 & 2.2 & 1.8 & 0.01 & 0.111 & 0.420 \\
\hline FC1 $15 \mathrm{~m} \mathrm{f}$ crest & 97.7 & 0.2 & 2.1 & 0.75 & 80 & 2.2 & 1.7 & 0.01 & 0.111 & 0.420 \\
\hline FC2 outer crest & 97.7 & 0.2 & 2.1 & 0.75 & 98 & 2.2 & 1.6 & 0.01 & 0.111 & 0.420 \\
\hline
\end{tabular}

Soil chemical analysis was conducted to assess the probability of chemical binding or dispersity. The results for the chemical analyses were pooled, largely due to the high degree of similarity in the composition of tailings material across the beach and are presented in Table 3. The chemistry did not indicate any chemical dispersity nor crusting potential that may significantly influence erodibility of the tailings substrate.

Table 3 Chemical analyses of the tailings material from the tailings storage facility beach

\begin{tabular}{lllllll}
\hline $\mathrm{pH}(\mathrm{KCl})$ & ${\mathrm{P} \mathrm{Bray1} \mathrm{mg} \mathrm{kg}^{-1}}$ & $\mathrm{EC} \mathrm{mS} / \mathrm{m}$ & $\mathrm{K} \mathrm{mg} \mathrm{kg}^{-1}$ & $\mathrm{Ca} \mathrm{mg} \mathrm{kg}^{-1}$ & $\mathrm{Mg} \mathrm{kg}^{-1}$ & $\mathrm{Na} \mathrm{mg} \mathrm{kg}^{-1}$ \\
\hline 9.0 & 5 & 36.2 & 42 & 1,624 & 83 & 14 \\
\hline
\end{tabular}

\subsection{Resultant wind speed factor as a result of landform geometry}

Hill slope gradient and slope length are used to express the effect of geometry on wind speeds. RWEQ assumes that the hill extends perpendicular to the wind and that the upwind toe of the hill is at the upwind edge of the field. Since the TSF extends perpendicular to the predominant wind direction, this assumption can be largely validated. The Queney (1948) equation is suitable and was adopted to express wind speed over low, gently sloping, smooth-profiled, narrow mountains where the effects of the earth's rotation and tropopause are negligible, and the height does not exceed $10 \%$ of the base. The $2 \mathrm{~m}$ high wind speed was calculated at various points along the slope and beach along the windward side of the tailings facility from the toe to the crest and over the beach area (with the assumption that the day wall is $2 \mathrm{~m}$ above the beach surface). The $\alpha=$ angle of slope (degrees), $S=$ slope length $(\mathrm{m})$ and $G$ (gradient or $G=\tan =H_{H} \div x_{h}$ ) was manipulated to calculate for differences in erosion rates when geometry is varied. Figure 3 outlines the variables in the geometrically induced wind speed formula in RWEQ that was applied for the TSF in the study.

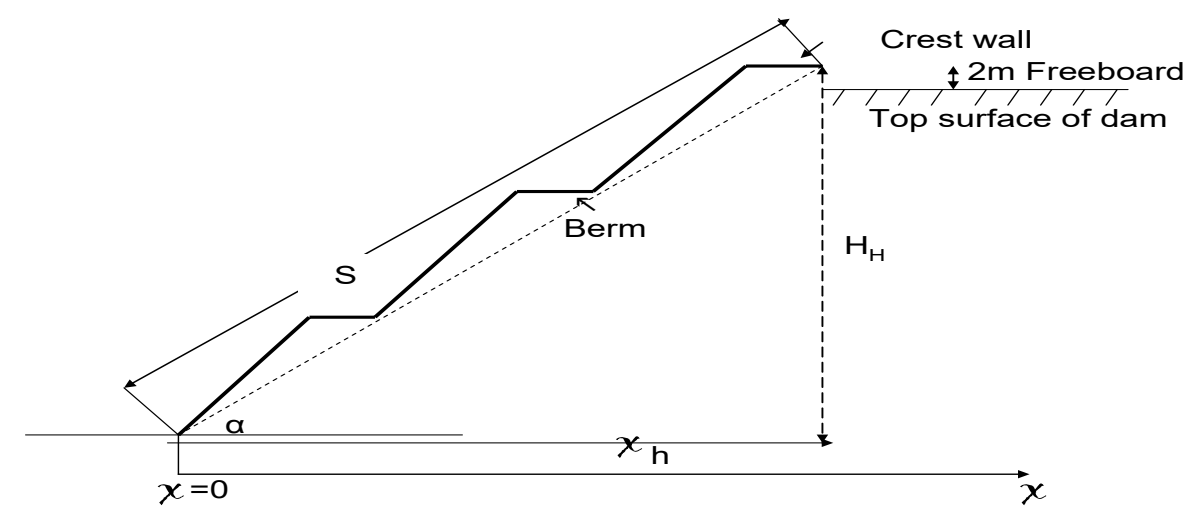

Figure 3 Slope profile for a tailings dam and parameters to describe the gradient and slope length 
The speed factors along the slope for different slope geometries calculated and summarised in Table 4 (only at the crest and over the beach area).

Table 4 Speed factors at the crest and over beach area for different slope geometries

\begin{tabular}{lllllll}
\hline Slope gradient (degrees) & Hh $(\mathbf{m})$ & $\mathbf{X h}(\mathbf{m})$ & $\mathbf{S}(\mathbf{m})$ & a & Speed factor crest & Speed factor beach \\
\hline 14 & & 70 & 83 & 40 & 1.50 & 1.44 \\
18 & 20 & 62 & 65 & 31 & 1.65 & 1.58 \\
26 & & 41 & 46 & 20 & 1.97 & 1.89 \\
14 & & 100 & 103 & 50 & 1.50 & 1.46 \\
18 & 25 & 77 & 81 & 39 & 1.65 & 1.60 \\
26 & & 54 & 57 & 26 & 1.97 & 1.90 \\
14 & & 120 & 124 & 60 & 1.50 & 1.47 \\
18 & 30 & 92 & 97 & 46 & 1.65 & 1.62 \\
26 & & 62 & 68 & 31 & 1.97 & 1.92 \\
\hline
\end{tabular}

The height data in Table 4 indicate that there was no significant difference in wind speeds calculated for different vertical height scenarios and therefore, the $30 \mathrm{~m}$ height was modelled as a worst-case scenario.

\subsection{Resultant wind eroded tailings losses}

The tailings particle gradation was used to calculate the erodible and potential dust generation fraction, with associated moisture constants. The measured hourly wind speed was used to calculate the Weibull constants at the height that the wind speed was measured $(10 \mathrm{~m})$ and converted to a wind speed at $2 \mathrm{~m}$ height (which is required as standard for wind erodibility calculations). Wind speed was adjusted over the tailings facility calculated from the hill equation and wind values, Wfs, and WFs were derived and to complete the RWEQ output (without mitigation).

The annual soil loss calculated from the methodology is presented in Table 5.

Table 5 Annual tailings soil loss $\left(\mathrm{kg} \cdot \mathrm{m}^{-2}\right)$ for 2008 climate data for three geometrical scenarios modelled for slope angles of 14,18 , and $26^{\circ}$ respectively (WF = weather factor) (continued next page)

\begin{tabular}{|c|c|c|c|c|c|c|c|c|}
\hline $\begin{array}{l}\text { Slope } \\
\text { gradient }\end{array}$ & $\begin{array}{l}\text { Interval } \\
\text { (15 days) }\end{array}$ & $\begin{array}{l}\text { WValue } \\
\text { beach }\end{array}$ & $\begin{array}{l}\text { WValue } \\
\text { crest }\end{array}$ & $\begin{array}{l}\text { WF } \\
\text { beach }\end{array}$ & $\begin{array}{l}\text { WF } \\
\text { crest }\end{array}$ & $\begin{array}{l}\text { Crest } \\
\left(\text { kg.m }{ }^{-2}\right)\end{array}$ & $\begin{array}{l}\text { Beach } \\
\left(\text { kg.m } \mathrm{m}^{-2}\right)\end{array}$ & $\begin{array}{l}\text { Total } \\
\left(\mathrm{kg} \cdot \mathrm{m}^{-2}\right)\end{array}$ \\
\hline & 1 to 15 & 176 & 215 & 5 & 6 & 0.008 & 0.033 & 0.041 \\
\hline & 16 to 30 & 30 & 41 & 1 & 1 & 0 & 0.007 & 0.007 \\
\hline & 31 to 45 & 83 & 109 & 2 & 3 & 0.002 & 0.017 & 0.019 \\
\hline & 46 to 60 & 23 & 31 & 1 & 1 & 0 & 0.005 & 0.005 \\
\hline & 61 to 75 & 8 & 12 & 0 & 0 & 0 & 0.002 & 0.002 \\
\hline & 76 to 90 & 1,441 & 1,657 & 43 & 50 & 0.283 & 0.052 & 0.335 \\
\hline & 91 to 105 & 0 & 1 & 0 & 0 & 0 & 0 & 0 \\
\hline & 106 to 120 & 0 & 0 & 0 & 0 & 0 & 0 & 0 \\
\hline & 121 to 135 & 227 & 273 & 7 & 8 & 0.011 & 0.042 & 0.053 \\
\hline & 136 to 150 & 0 & 0 & 0 & 0 & 0 & 0 & 0 \\
\hline $14^{\circ}$ & 151 to 165 & 26 & 35 & 1 & 1 & 0 & 0.006 & 0.006 \\
\hline
\end{tabular}




\begin{tabular}{|c|c|c|c|c|c|c|c|c|}
\hline & 166 to 180 & 0 & 0 & 0 & 0 & 0 & 0 & 0 \\
\hline & 181 to 195 & 11 & 16 & 0 & 0 & 0 & 0.003 & 0.003 \\
\hline & 196 to 210 & 18 & 24 & 1 & 1 & 0 & 0.004 & 0.004 \\
\hline & 211 to 225 & 49 & 63 & 1 & 2 & 0.001 & 0.01 & 0.011 \\
\hline & 226 to 240 & 794 & 927 & 24 & 28 & 0.103 & 0.082 & 0.185 \\
\hline & 241 to 255 & 2,429 & 2,788 & 73 & 84 & 0.439 & 0.126 & 0.565 \\
\hline & 256 to 270 & 1,674 & 1,953 & 50 & 59 & 0.307 & 0.083 & 0.39 \\
\hline & 271 to 285 & 3,704 & 4,242 & 111 & 127 & 0.668 & 0.194 & 0.862 \\
\hline & 286 to 300 & 4,259 & 4,826 & 128 & 145 & 0.76 & 0.231 & 0.991 \\
\hline & 301 to 315 & 2,760 & 3,153 & 83 & 95 & 0.496 & 0.146 & 0.642 \\
\hline & 316 to 330 & 62 & 78 & 2 & 2 & 0.013 & 0.001 & 0.014 \\
\hline & 331 to 345 & 511 & 597 & 15 & 18 & 0.094 & 0.025 & 0.119 \\
\hline & 346 to 360 & 1,632 & 1,892 & 49 & 57 & 0.298 & 0.082 & 0.38 \\
\hline & & & & & & 3.483 & 1.151 & 4.634 \\
\hline $\begin{array}{l}\text { Slope } \\
\text { gradient }\end{array}$ & $\begin{array}{l}\text { Interval } \\
\text { (15 days) }\end{array}$ & W beach & W crest & $\begin{array}{l}\text { WF } \\
\text { beach }\end{array}$ & $\begin{array}{l}\text { WF } \\
\text { crest }\end{array}$ & $\begin{array}{l}\text { Crest } \\
\left(\mathrm{kg} \cdot \mathrm{m}^{-2}\right)\end{array}$ & $\begin{array}{l}\text { Beach } \\
\left(\mathrm{kg} \cdot \mathrm{m}^{-2}\right)\end{array}$ & $\begin{array}{l}\text { Total } \\
\left(\mathrm{kg} \cdot \mathrm{m}^{-2} \text { ) }\right.\end{array}$ \\
\hline & 1 to 15 & 447 & 526 & 13 & 16 & 0.082 & 0.022 & 0.104 \\
\hline & 16 to 30 & 118 & 148 & 4 & 4 & 0.023 & 0.004 & 0.027 \\
\hline & 31 to 45 & 288 & 355 & 9 & 11 & 0.056 & 0.011 & 0.067 \\
\hline & 46 to 60 & 95 & 120 & 3 & 4 & 0.019 & 0.003 & 0.022 \\
\hline & 61 to 75 & 45 & 59 & 1 & 2 & 0.009 & 0.001 & 0.01 \\
\hline & 76 to 90 & 2,765 & 3,109 & 83 & 93 & 0.489 & 0.154 & 0.643 \\
\hline & 91 to 105 & 6 & 8 & 0 & 0 & 0 & 0.001 & 0.001 \\
\hline & 106 to 120 & 0 & 1 & 0 & 0 & 0 & 0 & 0 \\
\hline & 121 to 135 & 531 & 617 & 16 & 19 & 0.087 & 0.052 & 0.139 \\
\hline & 136 to 150 & 0 & 0 & 0 & 0 & 0 & 0 & 0 \\
\hline & 151 to 165 & 93 & 115 & 3 & 3 & 0.018 & 0.008 & 0.026 \\
\hline $18^{\circ}$ & 166 to 180 & 0 & 0 & 0 & 0 & 0 & 0 & 0 \\
\hline & 181 to 195 & 50 & 64 & 1 & 2 & 0.009 & 0.003 & 0.012 \\
\hline & 196 to 210 & 67 & 85 & 2 & 3 & 0.013 & 0.003 & 0.016 \\
\hline & 211 to 225 & 158 & 193 & 5 & 6 & 0.03 & 0.007 & 0.037 \\
\hline & 226 to 240 & 1,629 & 1,852 & 49 & 56 & 0.291 & 0.088 & 0.379 \\
\hline & 241 to 255 & 4,607 & 5,168 & 138 & 155 & 0.813 & 0.259 & 1.072 \\
\hline & 256 to 270 & 3,413 & 3,874 & 102 & 116 & 0.61 & 0.184 & 0.794 \\
\hline & 271 to 285 & 6,955 & 7,787 & 209 & 234 & 1.226 & 0.392 & 1.618 \\
\hline & 286 to 300 & 7,635 & 8,486 & 229 & 255 & 1.337 & 0.44 & 1.777 \\
\hline
\end{tabular}




\begin{tabular}{|c|c|c|c|c|c|c|c|c|}
\hline & 301 to 315 & 5,134 & 5,741 & 154 & 172 & 0.904 & 0.291 & 1.195 \\
\hline & 316 to 330 & 176 & 211 & 5 & 6 & 0.033 & 0.008 & 0.041 \\
\hline & 331 to 345 & 1,053 & 1,199 & 32 & 36 & 0.188 & 0.057 & 0.245 \\
\hline & 346 to 360 & 3,233 & 3,653 & 97 & 110 & 0.575 & 0.177 & 0.752 \\
\hline & & & & & & 6.812 & 2.165 & 8.977 \\
\hline $\begin{array}{l}\text { Slope } \\
\text { gradient }\end{array}$ & $\begin{array}{l}\text { Interval } \\
\text { (15 days) }\end{array}$ & W beach & W crest & $\begin{array}{l}\text { WF } \\
\text { beach }\end{array}$ & $\begin{array}{l}\text { WF } \\
\text { crest }\end{array}$ & $\begin{array}{l}\text { Crest } \\
\left(\mathrm{kg} \cdot \mathrm{m}^{-2}\right)\end{array}$ & $\begin{array}{l}\text { Beach } \\
\left(\mathrm{kg} \cdot \mathrm{m}^{-2}\right)\end{array}$ & $\begin{array}{l}\text { Total } \\
\left(\mathrm{kg} \cdot \mathrm{m}^{-2}\right)\end{array}$ \\
\hline & 1 to 15 & 1,787 & 2,157 & 54 & 65 & 0.34 & 0.076 & 0.416 \\
\hline & 16 to 30 & 769 & 979 & 23 & 29 & 0.154 & 0.025 & 0.179 \\
\hline & 31 to 45 & 1,611 & 2,014 & 48 & 60 & 0.317 & 0.058 & 0.375 \\
\hline & 46 to 60 & 656 & 841 & 20 & 25 & 0.132 & 0.021 & 0.153 \\
\hline & 61 to 75 & 416 & 549 & 12 & 16 & 0.086 & 0.011 & 0.097 \\
\hline & 76 to 90 & 7,710 & 8,908 & 231 & 267 & 1.402 & 0.392 & 1.794 \\
\hline & 91 to 105 & 83 & 115 & 2 & 3 & 0.018 & 0.001 & 0.019 \\
\hline & 106 to 120 & 24 & 37 & 1 & 1 & 0.006 & 0 & 0.006 \\
\hline & 121 to 135 & 1,921 & 2,292 & 58 & 69 & 0.36 & 0.087 & 0.447 \\
\hline & 136 to 150 & 5 & 9 & 0 & 0 & 0 & 0.001 & 0.001 \\
\hline & 151 to 165 & 547 & 691 & 16 & 21 & 0.109 & 0.018 & 0.127 \\
\hline $26^{\circ}$ & 166 to 180 & 0 & 0 & 0 & 0 & 0 & 0 & 0 \\
\hline & 181 to 195 & 370 & 479 & 11 & 14 & 0.075 & 0.011 & 0.086 \\
\hline & 196 to 210 & 432 & 551 & 13 & 17 & 0.086 & 0.015 & 0.101 \\
\hline & 211 to 225 & 841 & 1,049 & 25 & 31 & 0.165 & 0.031 & 0.196 \\
\hline & 226 to 240 & 4,968 & 5,804 & 149 & 174 & 0.914 & 0.242 & 1.156 \\
\hline & 241 to 255 & 12,578 & 14,488 & 377 & 435 & 2.28 & 0.647 & 2.927 \\
\hline & 256 to 270 & 10,194 & 11,867 & 306 & 356 & 1.868 & 0.504 & 2.372 \\
\hline & 271 to 285 & 18,645 & 21,418 & 559 & 643 & 3.372 & 0.967 & 4.339 \\
\hline & 286 to 300 & 19,333 & 22,061 & 580 & 662 & 3.474 & 1.025 & 4.499 \\
\hline & 301 to 315 & 13,670 & 15,699 & 410 & 471 & 2.471 & 0.71 & 3.181 \\
\hline & 316 to 330 & 810 & 994 & 24 & 30 & 0.156 & 0.032 & 0.188 \\
\hline & 331 to 345 & 3,244 & 3,797 & 97 & 114 & 0.597 & 0.158 & 0.755 \\
\hline & 346 to 360 & 9,344 & 10,838 & 280 & 325 & 1.707 & 0.467 & 2.174 \\
\hline & & & & & & 20.089 & 5.499 & 25.588 \\
\hline
\end{tabular}

The annual soil loss is for the worst-case scenario when the soil is at AD conditions. For the periods when the soil water content is close to the DUL, the erosion will be about 0.75 times the soil loss at AD conditions. Soil loss is the highest over the day of year period 226 to 315 (mid-July to mid-October). Over this 3-month period, the soil loss is about $72 \%$ of the total annual soil loss. The soil loss is over the whole tailings facility (all wind 
directions) but the majority was predicted in the prevailing wind direction which is southeast to south-southeast, especially where the longest beaches occur parallel to the prevailing wind direction.

The slope gradient of the TSF had the largest effect on wind speed and therefore, on soil loss. The annual soil loss is $46.3 \mathrm{t} / \mathrm{ha}$ for a gradient of $14^{\circ}$ but is $255.9 \mathrm{t} / \mathrm{ha}$ for a gradient of $26^{\circ}$. Most of the soil loss was from the slope-to-crest areas, where the beach areas generated $65-70 \%$ less dust than the slope areas. The comparable soil loss for the modelled scenarios is presented in Figure 4.

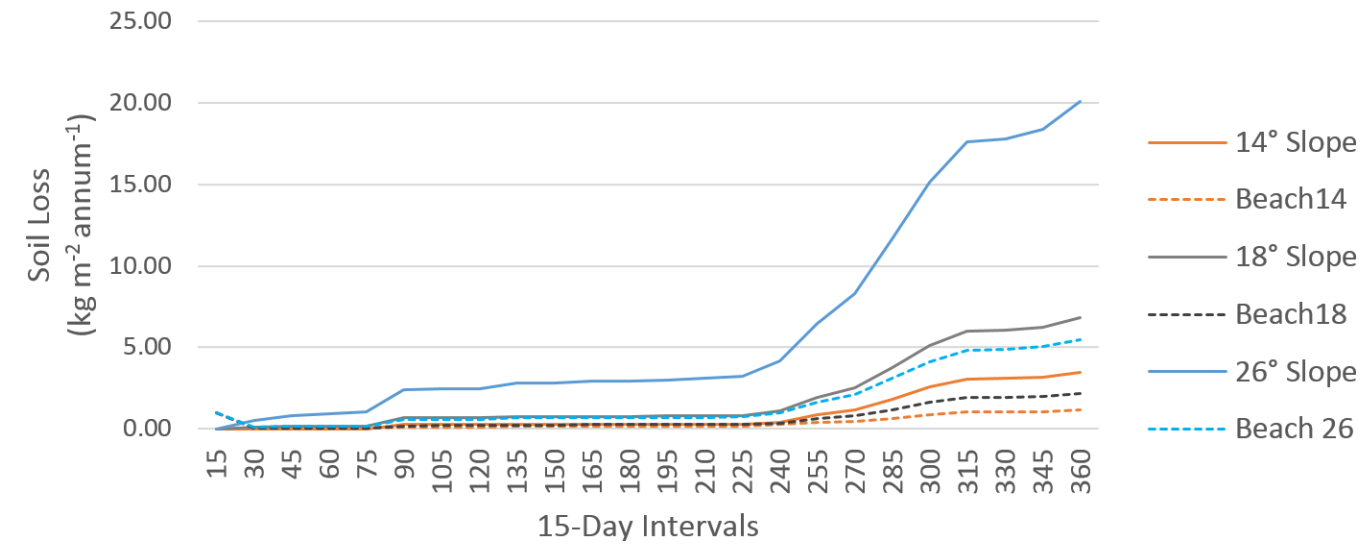

Figure 4 Comparable soil loss $\left(\mathrm{kg} \mathrm{m}^{-2} \mathrm{yr}^{-1}\right)$ for 14,18 , and $26^{\circ}$ slope geometry scenarios

The tailings measured are erodible by wind, with the naturally occurring wind leading to average losses of over $4.6 \mathrm{~kg}$ of material per square metre of beach per year. This is a significant volume and relates to an average loss of nearly $5 \mathrm{~cm}$ of tailings from the entire facility every year. However, we have established that this is not consistent across the landscape and that some sections will have higher losses, and some will even have gains due to deposition which is demonstrated in subsection 3.5 below.

Typically, the coarse-to-fine sand particulates are most prone to aeolian transport and the outer beach is expected to be more prone to dust generation, but since the material is poorly graded, the erosion modelling showed no significant differences based on particle size and spatially-related tailings characteristics. The chemical analyses revealed no predisposition to dispersion and therefore the dust risk profile could only be drawn on the basis of dominant wind direction, wind speeds compounded by geometrical effects and beach length. The resulting dust risk profile is shown in Figure 5 where the entire north-eastern triangle of approximately 300 ha (30\%) has been outlined as a critical dust source on this TSF.

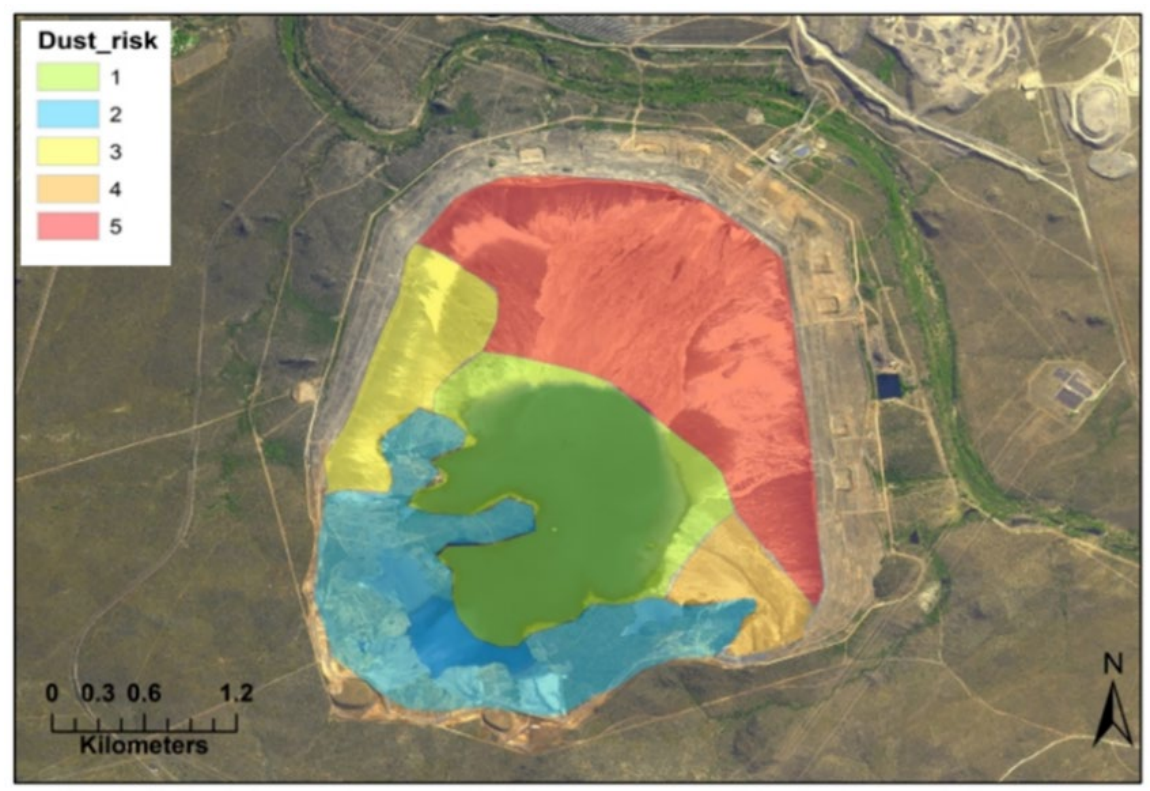

Figure 5 Dust risk zone modelled output from the wind shear analysis for the TSF 


\subsection{Wind erosion mitigation}

To determine the effect of dust mitigation solutions, 'untreated' and 'treated' sections were modelled. Only the beach area was considered and only one Wf was selected to illustrate the erosion process with and without erosion control measures. The selected $\mathrm{Wf}$ is for an outer slope gradient of $18^{\circ}$ and interval 241 to 255 (Table 5, column 1, wind interval) was selected. The value of the Wf on the beach at the crest is 137 and this value will decrease (for a negative slope of $4 \%$ to the pool) to a value of 128 , at a distance $500 \mathrm{~m}$ from the crest and will then remain constant up to $1,100 \mathrm{~m}$ from the crest. The beach was divided into five sections of $100 \mathrm{~m}$ each and one section of $600 \mathrm{~m}$. The average $\mathrm{Wf}, \mathrm{WF}$, maximum transport capacity $\left(\mathrm{Q}_{\max }\right)$, and critical field length(s) for each section without erosion control measures are summarised in Table $6 . W F, Q_{\max }$ and $s$ were calculated with air density as $1.1 \mathrm{~kg} \cdot \mathrm{m}^{-3}$.

Table 6 The wind factor (Wf), weather factor (WF), maximum transport capacity $\left(\mathrm{Q}_{\max }\right.$ ), and critical length(s) for the six sections on the dam from the crest (section 1) inward towards the pool (sections 2 to 6 )

\begin{tabular}{lllll}
\hline Section & Wf & WF & $\mathbf{Q}_{\max }$ & $\mathbf{S}$ \\
\hline 1 & 137 & 15 & 1,265 & 61 \\
2 & 135 & 15 & 1,247 & 61 \\
3 & 133 & 15 & 1,228 & 61 \\
4 & 131 & 15 & 1,210 & 62 \\
5 & 129 & 14 & 1,191 & 62 \\
6 & 128 & 14 & 1,182 & 62 \\
\hline
\end{tabular}

Using the input data derived in Table 6, the comparable mass loss $Q(x)$ can be evaluated for the sections outlined with and without mitigation options. Mass movement downwind was calculated as a function of distance downwind. The results, expressed as Qin and Qout for each section, as well as the actual soil loss/gain in each section, and the average soil loss as function of downwind distance is summarised in Table 7 for unmitigated source areas. Table 8 presents a summary of the mass movement, expressed as Qin and Qout, where control measures was applied and modelled for on only the first two sections on the beach. Irrigation was selected as the erosion control measure in the model.

Table 7 Soil loss/gain without erosion control on the various sections on the beach

\begin{tabular}{|c|c|c|c|c|}
\hline Section & Qin kg. $\mathrm{m}^{-1}$ & Qout kg.m ${ }^{-1}$ & Soil loss/gain kg.m ${ }^{-1}$ & Average soil loss $\mathrm{kg} \cdot \mathrm{m}^{-2}$ \\
\hline 1 & 0 & 1,235 & 1,235 (loss) & 12.35 \\
\hline 2 & 1,235 & 1,247 & 12 (loss) & 6.24 \\
\hline 3 & 1,247 & 1,228 & 19 (gain) & 4.09 \\
\hline 4 & 1,228 & 1,210 & 18 (gain) & 3.03 \\
\hline 5 & 1,210 & 1,191 & 19 (gain) & 2.38 \\
\hline 6 & 1,191 & 1,182 & 9 (gain) & 1.07 \\
\hline
\end{tabular}


Table 8 Soil loss/gain with erosion control on two sections of the beach

\begin{tabular}{|c|c|c|c|c|}
\hline Section & Qin kg. $\mathrm{m}^{-1}$ & Qout kg.m ${ }^{-1}$ & Soil loss/gain kg.m ${ }^{-1}$ & Average soil loss kg. $\mathrm{m}^{-2}$ \\
\hline 1 & 0 & 54 & 54 (loss) & 0.54 \\
\hline 2 & 54 & 112 & 58 (loss) & 0.56 \\
\hline 3 & 112 & 1,228 & 1,116 (loss) & 4.09 \\
\hline 4 & 1,228 & 1,210 & 18 (gain) & 3.03 \\
\hline 5 & 1,210 & 1,191 & 19 (gain) & 2.38 \\
\hline 6 & 1,191 & 1,182 & 9 (gain) & 1.07 \\
\hline
\end{tabular}

As depicted in Tables 7 and 8, the erodible material is transported downwind from the source section onto the next receptor section and not all the erodible material will therefore leave the site. Erosion losses were drastically reduced on the two sections of beach area where mitigation measures were applied. The first $100 \mathrm{~m}$ section on the beach was the most susceptible to wind erosion as well as the section immediately after the 'treated' area (section 3 ). This demonstrates that mitigation efforts can be designed according to the site-specific geometrical and material property characteristics.

\section{Conclusion}

The RWEQ was applied to model the extent of wind erosion for different geometrical scenarios on a large-scale porphyritic phosphorite tailings storage facility in a semi-arid environment in South Africa. Detailed analysis of field information was used to compile the dust risk assessment. High-risk dust prone areas were delineated to advise the mine on dust control options during their operation and after closure. It was found that slope geometry had the most influence on dust generation across the modelled parameters. The $26^{\circ}$ slope configuration liberated exponentially more dust compared to 14 and $18^{\circ}$ gradients. The annual soil loss is $46.3 \mathrm{t} /$ ha for a gradient of $14^{\circ}$ but is $255.9 \mathrm{t} /$ ha for a gradient of $26^{\circ}$. It was also evident that most soil loss occurred during a 3-month period from approximately $30 \%$ of the total exposed tailings surface area, predominantly in a downwind direction. Comparing unmitigated and mitigated dust control effects proved that the first $100 \mathrm{~m}$ on the tailings beach showed the highest level of exposure. The modelled output showed a drastic reduction in wind erosion loss where dust mitigation was implemented (irrigation), although some erosive loss still occurs and is transferred to the downwind sections; not all dust is blown offsite. The mine therefore could budget for, and apply dust solutions on, the high-risk delineated areas, intensify mitigation efforts with hands-on systems during the indicated dust prone months. These proactive management interventions will drastically reduce dust risk.

Whilst the modelling approach followed here proved suitable to attain the objectives of the specific TSF management towards decommissioning and closure, the potential of the approach for future TSF design is more far-reaching. Information about the design detail-relating to scale, geometry, construction methodology, and proximity to sensitive receptors-can be imported into the model. This approach may advise dust risk scenarios informing trade-off decisions relating to site location and final landscapes. The upfront dust management and cost and wind erosion risk implications of the operation can thus be understood in advance. The required operational and closure criteria can now be properly planned for from the onset of the TSF design and commissioning phase. This will decrease costs over life-of-mine and have the additional benefits of legal compliance with greater chances at achieving final closure. For legacy facilities, decommissioned TSFs, waste rock dumps, or other dust generating stockpiles, this approach can provide input into the orientation, reshaping requirements (geometrical design in slope lengths, angles), final capping material requirements (soil type, properties) which can all be modelled through this process. 
Finally, tailings design engineers can apply the proposed process as part of final landscape design criteria for closure. Future TSFs can be designed more in equilibrium with erosive forces which will reduce the risk of long-term cover and slope failures and ensuring that TSFs will not become prolonged dust sources that pose long-term hazards to human and environmental health.

\section{Acknowledgement}

We would like to acknowledge Agreenco Environmental Projects (Pty) Ltd for giving us the opportunity to present this information. I would also want to thank the previous owner of the mine for believing in this approach and for implementing the successful dust mitigation scheme that we have proposed.

\section{References}

Amponsah-Dacosta, F \& Blight, GE 2002, 'The effects of wind on the surfaces of mine tailings dams', Proceedings of the 33' Conference of the International Erosion Control Association, Orlando.

Blight, GE 2008, 'Wind erosion of waste impoundments in arid climates and mitigation of dust pollution', Waste and Resource Management, vol. 26(6), pp. 523-533.

Fryrear, D W \& Saleh, A 1993, 'Field wind erosion: Vertical distribution', Soil Science, vol. 5, issue 4, pp. 294-300.

Fryrear, DW, Saleh, A, Bilbro, JD, Schomberg, HM, Stout, JE, \& Zobeck, TM 1998, Revised Wind Erosion Equation (RWEQ), Wind Erosion and Water Conservation Research Unit, United States Department of Agriculture-Agricultural Research Service, Southern Plains Area Cropping Systems Research Laboratory Technical Bulletin No. 1.

Hagen, LJ 1991, 'A wind erosion prediction system to meet user needs', Journal of Soil and Water Conservation, vol. 46, pp. $106-111$. Haagner ASH, Jansen van Rensburg, I, Champion G \&Van Wyk, SJ 2014, 'Dust Risk Assessment and Management Plan for a South African mine heading towards closure', Proceedings of the 9th International Mine Closure Conference, Johannesburg.

Liebenberg-Enslin, H 2014, A functional dependence analysis of wind erosion system parameters to determine a practical approach to wind erosion assessments, PhD thesis, University of Johannesburg, Johannesburg.

Pasak, V 1967, Factors underlying the wind erosion of soils. In Dvorak \& Novak 1994. Soil Conservation and silviculture. Elsevier. Amsterdam, pp. 401p

Queney, P 1948, 'The problem of air flow over mountains: a summary of theoretical studies', Bulletin of the American Meteorological Society, vol. 29, pp. 16-25.

South African Weather Service 2008, Ba-Phalaborwa weather station, viewed 5 August 2010, http://saws.co.za/phalaborwa

Shao, Y 2008, Physics and Modelling of Wind Erosion, Springer, Berlin, p. 420.

Singh, AB 1994, Wind erosion: Mechanics of saltation and dust generation, PhD thesis, unpublished, Texas Tech University, Lobbock. Stout, JE \& Zobeck, TM 1996, 'The Wolfforth field experiment: A wind erosion study', Soil Science, vol. 161, issue 9, pp. 616-632.

Rademeyer, B 2007, The influence of Environmental impacts on Tailings Impoundment design, PhD Thesis, University of Pretoria, Pretoria.

Van Wyk, SJ 2010, Dust Management Best Practice Guideline for Tailings Storage Facilities, internal guideline document prepared for AngloGold Ashanti, p. 154.

Van Wyk, SJ 2015, Revised Dust Management Best Practice Guideline for Tailings Storage Facilities, internal guideline document prepared for AngloGold Ashanti, p. 168.

Vermeulen, NJ 2001, State of Gold Tailings, PhD Thesis, University of Pretoria, Pretoria.

Visser, SM 2004, Modelling Nutrient Erosion by Wind and Water in northern Burkina Faso, PhD thesis, Wageningen University, Wageningen. 
